gælder deres konkrete indhold. Dybest set er det kun hans fortolkning af »PaaskeLilien «, der bider sig fast $\mathrm{i}$ læserens bevidsthed som en virkelig nutidigt vedkommende tekst, ganske simpelt fordi dette digt løst ud af sin sammenhæng med det mysteriespil, hvori det er indføjet, med rette er blevet en klassiker i dansk litteratur. At dette er tilfældet, skyldes digtets egne kvaliteter $i$ henseende til form og først og fremmest indhold. Pointen i Anders Holms fortolkning er lig med hele det hermeneutiske aspekt af den typologiske fortolkningsmåde: det forhold, at »det fortidige kan opstå i det nutidige« (s. 75). »Paaske-Lilien« handler ganske enkelt om dette forhold, og eftersom opstandelsesmotivet er det centrale heri, falder digtets indhold og den filosofiske hermeneutiks analyse af menneskets forholden sig til historien godt sammen. Og med "Paaske-Lilien« som udgangspunkt lukker resten af DV-forfatterskabet sig selvfølgelig op, - og læseren sidder tilbage, klogere på en tidlig periode i Grundtvigs liv og med ønsket om, at undersøgelsen følges op af tolkninger af de senere, klassiske tekster i Grundtvigs store forfatterskab. I en tid, hvor Grundtvig-kritikken făr uforholdsmæssig stor betydning, er det velgørende, at yngre forskere tager forfatterskabet op med en anderledes, og langt mere positiv indfaldsvinkel.

\title{
Den mageløse Grundtvig
}

\section{Af Jørgen Carlsen}

A. M. Allchin, S. A. J. Bradley, N. A. Hjelm, J. H. Schjørring ed.: Grundtvig in International Perspective. Studies in the Creativity of Interaction. Aarhus University Press, Gylling 2000, ISBN 877288835 0. 209 s.

"One cannot help feeling, that there is something strange about this man. He is more scholarly than the scholars and more popular than the publicists. He does not like to fit into our usual ways of categorising people, even of categorising people of exceptional ability and vision.« (s. 6).

Således lyder A.M. Allchins indledende karakteristik af N. F. S. Grundtvig i bogen »Grundtvig in International Perspective«, der udkom sidste år som det 33. bind $i$ rækken af skrifter, udgivet af Grundtvig-Selskabet. Bag udgivelsen står foruden hovedredaktøren A.M. Allchin (professor ved University College of North Wales i Bangor, UK), S.A.J. Bradley (docent ved University of York, England), Norman A. Hjelm (præst Wynnewood, Philadelphia, USA) og teologen Jens Holger Schjørring (professor ved Århus Universitet).

Udgivelsen kan ses som en slags follow-up på en tidligere engelsksproget antologi af samme karakter. I 1993 udgav Grundtvig-Selskabet bogen »Heritage and Prophecy « - også dengang redigeret af A.M. Allchin og Jens Holger Schjørring i selskab med andre. Denne antologi havde undertitlen: »Grundtvig and the Englisch-Speaking World«. Som man vil kunne ane, er der en påfaldende glidning i perspektivet fra den første til denne anden udgivelse »Grundtvig in International Perspective«. Vi bevæger os fra det engelsk-sprogede domæne videre ud i verden. Dermed er der også anslået et skjult 
ledemotiv for bogens artikler: for så vidt Grundtvig skal kunne anskues frugtbart i et internationalt perspektiv, må det være det universelle ved Grundtvig, der efterspørges - ikke det specifikt dansk-nationale. Det er ikke en Grundtvig til indvortes brug for de indforståede grundtvigianere, men en Grundtvig, der er på vej ud i verden og ind i det 21. århundrede. Og det besynderlige paradoks er måske, at bogen netop ved at vælge dette perspektiv kan virke frugtbart tilbage på Grundtvig-billedet her i landet mellem "bøgestammer, under nattergalesang."

Lad mig illustrere det ved at opholde mig ved et enkelt ord. I bogen finder man to forskellige versioner af et af de uomgængelige ord, når talen er om Grundtvigs liv og virke. Det drejer sig om ordet »mageløs«. Langt oftest optræder ordet i sin forventelige og forudsigelige oversættelse »matchless«. Men indimellem træffer man også på oversættelsen »unparalleled«. De er begge rimelige og dækkende, men jeg skal ikke lægge skjul på, at jeg finder stort behag i oversættelsen »unparallelled «. Hvorfor? Fordi ordet overrasker og kommer bag på én. Det drejer i hvert fald den refleksagtigt forventede betydning et par grader. Ordet stiller sig i bogstaveligste forstand på tværs. Det bryder for det første med det forventede - og det aftvinger for det andet synet på Grundtvig nye betydninger: hans liv var alt andet end geometrisk forudsigeligt, hvad enten man tænker på parallelle linier eller kræfternes parallelogram. Bare dette prunkløse og lidt uforsagte ord "unparalleled" er nok til at sætte tankerne og forestillingsevnen i sving. Denne milde form for "Verfremdung" at opleve Grundtvig igennem en anden sproglig optik er i sig selv produktiv og erkendelsesbefordrende.

At Grundtvig gør "mageløse» opdagelser er i sig selv mageløst. Man kan ikke bare forfølge et bestemt spor i Grundtvigs liv og tænkning og så på forhånd regne ud, hvad næste station må være. Finn Abrahamowitz har fortalt, at han i sit arbejde med sin netop udkomne Grundtvig-bog havde valgt at følge hans livsbane slavisk fra år til år og gang på gang blev overrasket over, hvad der gemte sig bag det næste årstal, selv om han naturligvis ikke har været ubekendt med Grundtvigs biografi på forhånd. Grundtvigs livsbane er ikke noget stafetløb, for stafetten er ikke den samme løbet igennem. Den mistes ofte, eller glemmes eller smides måske ligefrem væk med vilje. Der er snarere tale om et orienteringsløb eller måske er der slet ikke tale om noget løb, men en nærmere en skovtur, hvor han bevæger sig ad snoede stier, vender om, går tilbage, ombestemmer sig, går nye veje, indtil han til sidst blot nyder turen og dvæler ved nattergalesangen. Hans liv var som bekendt præget af brud, kovendinger og selvopgør. Han gør sig til talsmand for rationalisme, romantik, skriftfetichisme, lovprisning af »det levende ord«, videnskabsdyrkelse og kritik af »drengevidenskabeligheden«, skriftklogskab, der ser ned på »bogormesygen«, kongetro tilslutning til enevælden og lige så begejstret forsvar for »folkerådet «, fædrelandskærlig nationalisme og globaliseret universalisme, og gennem det hele løber faser af poserende fromhed, dybe anfægtelser, forfængelighed, stolthed, ydmyghed, klarsyn og rablende galskab.

I den forstand er Grundtvig et menneske på tværs. Han tænker diagonalt, overraskende og uforudsigeligt, og ikke sjældent tænker og handler han på tværs af sig selv, så han ligefrem forbløffes over sig selv. Men selv er han som bekendt alt andet end blind for dette forhold. Han tager alle disse modsigelser på sig med en nonchalant gestus: hvis klarhed er målet, kan det vel ikke samtidig være vandringsstaven på vejen! Man kunne ligefrem kalde ham en oplyst fumlegænger. Han er ikke bare bevidst om sine rødder, men også om sine fødder, og påberåber sig med de levendes 
ret et standpunkt, indtil han finder et nyt: »Her går jeg, jeg kan ikke andet, så hjælpe mig Gud!« - Det sidste er naturligvis ikke hans egne ord, men det kunne meget vel have været et af hans valgsprog.

Grundtvig er altså ikke sådan at bringe på formel. Selv blandt de exceptionelle synes han ifølge Allchin at være en undtagelse. Han er vanskelig at identificere og entydiggøre. Det er den omfattende Grundtvig-litteratur på dansk et tydeligt eksempel på. Vi har som bekendt ikke bare en Grundtvig-forskning, vi har også en omfattende Grundtvig-debat, forskelle i kirkesyn, højskolesyn, forståelse af folkelighed, for slet ikke at tale om de vidt forskellige politiske orienteringer, der påberåber sig arven fra Grundtvig, omfattende stort set alle partier i det danske folketing.

«Et menneske er så rigt, som de modsætninger, det er i stand til at rumme«, har religionshistorikeren Vilhelm Grønbech engang udtalt. Hvis det er tilfældet, så må Grundtvig under alle omstændigheder siges at have været et rigt menneske. At der stadigvæk står blæst om ham, er vel et udtryk for, at han på en ejendommelig måde stadig er en levende samtalepartner og ikke en »død helgen«.

Denne indre modsigelsesfyldthed og spænding går igennem flere af bidragene $\mathrm{i}$ bogen. Den bliver også understreget af hovedredaktøren A.M. Allchin i slutningen af sin meget instruktive indledning. Her føler han sig fristet til at citere følgende linier fra en gammel julesalme af Charles Wesley:

He deigns in flesh to appear

Widest extremes to join,

To bring our vileness near

And make us all divine.

(Han nedlader sig til at blive kød

at forene de yderste modsætninger

for at bringe vor gemenhed på tæt hold

og gøre os alle guddommelige)

Det kunne altså næsten synes, som om Grundtvig alligevel - mod sin erklærede vilje kandiderer til en helgenglorie. Men en formildende omstændighed er det vel, at det ikke er en dansker, der står for denne hyldest, og det skal retfærdigvis siges, at bogen hele vejen igennem er præget af en nøgtern analytisk intention og vilje til at behandle stoffet sagligt og argumenterende.

Men en sådan mangel på entydighed gør det naturligvis vanskeligt at - undskyld mig udtrykket - »markedsføre» Grundtvig uden for Danmarks grænser. Hvordan skal man egentlig forvente, at andre fra et andet sprogområde kaster sig videbegærligt over ham, når det forholder sig sådan, at talen om ham, om jeg så må sige, ikke er særlig "fast i kødet" - hvor »løs« må da ikke al fremmed tale være om ham?

Indimellem kan man som dansker blive helt desorienteret - og også en smule forlegen - når man møder Grundtvigs sange og samler i fremmed skikkelse, ikke mindst når der er tale om oversættelse til engelsk. Det er, som om der tales et andet sted fra - undertiden et meget andet sted fra. Ordene klinger forkert, han gøres ofte mere spirituel end godt er, og kan i værste fald ligefrem lyde new age-agtig. Der er især en ting, jeg har vanskeligt ved at forlige mig med. Det er, når ordet »ånd" mekanisk oversættes til «spirit«. Det er lige før, man føler sig kaldet til at minde om, 
at ånd hos Grundtvig er et højst jordisk, ja ligefrem "kødeligt» begreb - at "åndefavnetaget« peger mere i retning af et samleje end et spiritistmøde, hvis man endelig skal vælge side. Der er en yndefuld og nænsomt svævende balance i Grundtvigs forhold til ordene, som gør det så forbandet svært at oversætte ham til andre sprog. Eller med Allchins rammende formulering: Grundtvig synes at være »impossibly Danish.»

Så meget mere beundring må det vække at se udenlandske forskere kaste sig ud i forsøg på en fortolkning af centrale temaer hos Grundtvig, sådan som det er sket med denne bog. Bogen har betegnende nok undertitlen »Studies in the Creativity of Interaction«, og det kan forstås på flere måder. Dels spilles der naturligvis på Grundtvigs egen tale om den »levende vekselvirkning«. Dels er de mange forskellige bidrag i sig selv udtryk for en sådan levende vekselvirkning, fordi den grundtvigske tekst naturligvis selv bliver sat i svingninger ved at blive anskuet fra andet og mere end et pæredansk udsigtspunkt. Som bekendt er det bekendte sjældent det erkendte. Det, man tager for givet, ænser man ikke på samme måde som det, man nærmer sig med nysgerrighed og indføling.

Det interessante er altså anskuelsen af Grundtvig i denne nye, internationale kontekst. $\mathrm{Og}$ det befriende og bemærkelsesværdige er den gennemgående vilje hos de forskellige udenlandske forskere til at præstere fremmed tale om Grundtvig, som bestemt ikke er »løs«. Artiklerne, som er indlæg fra tre forskellige Grundtvig-konferencer (Chicago 1995, Køge 1997, Calcutta 1999), er præget af en stor vilje til at forbinde sig med temaer hos Grundtvig, som kan virke inspiratorisk og erkendelsesbefordrende tilbage på dem selv - og dermed også på alle os andre Grundtviginteresserede.

Lad det være sagt ligeud. Bogen flytter ikke i sig selv milepæle i Grundtvig-forskningen. De forskellige indlæg abonnerer flittigt på den etablerede Grundtvig-exegese her i landet og adskillige af de hjemlige koryfæer er jo selv repræsenteret med gedigne bidrag: Christian Thodberg, Jakob Balling, K. E. Bugge og Holger Bernt Hansen. Men flyttes der ikke milepæle, så flyttes til gengæld fokus på Grundtvig. På samme måde som en gennemtænkt ophængning af malerier på en kunstudstilling kan bringe billederne i samtale med hinanden og aftvinge dem nye facetter, på samme måde indgår bidragene i en konstellation, der på interessant vis ændrer lyssætningen på Grundtvig.

Siges der ikke afgørende nyt om Grundtvig selv i denne antologi er det til gengæld befriende at konstatere, at bidragene står i et fortroligt forhold til den aktuelle Grundtvig-forskning og at de er velgørende sikre i deres forståelse af Grundtvigs antignostiske, jordbundne åndelighed.

Grundtvigkendere vil vide, at dette antispirituelle livs- og menneskesyn ikke mindst skyldes Grundtvigs dybe betagelse af den sydfranske kirkefader Irenæus fra det 2. århundrede, og det er betegnende at navnet Irenæus dukker op, oftest en passant $i$ adskillige af bogens artikler, bl.a. A. M. Allchins egen artikel »The Holy Spirit in the Teaching of N.F.S. Grundtvig"

De mere overordnede perspektiveringer i bogens bidrag er først og fremmest af $ø$ kumenisk, økologisk og pædagogisk karakter. I det følgende et par nedslag blandt de 14 bidrag fra en stor del af verden: Europa, Nord- og Sydamerika, og Asien (Indien): Interessant er den amerikanske teolog Michael Roots jævnføring mellem Grundtvig og »århusteologen« Regin Prenter, der modificerer den barthske teologi med Grundtvigs tanke om sammenhængen mellem den skabte verden og forløsningen ved Kristus. 
Roots påpeger Grundtvigs betydning for den økumeniske diskussion ved i sit kirkesyn at repræsentere førreformatoriske, »katolske» træk, som forplanter sig videre hos Prenter. Denne Grundtvig-inspiration forlener Prenters dogmatik med en »rummelig ortodoksi« ("generous orthodoxy«), som gør den frugtbar i moderne økumenisk tænkning - ikke mindst fordi den overskrider en ren defensiv og konservativ reaktion på den moderne samfundsudvikling: Vi lever ikke i en forladt verden. Heller ikke en Gudsforladt verden. Gud er med os. Han følger os, hvor vi går. Skal vi være lidt finurlige, kan vi netop trøste os ved, at det tværtimod er ham, der ved Kristus forlader os vore synder!

Den finske professor Gustav Björkstrand fra akademiet i Aabo har nogle bemærkelsesværdige iagttagelser med inspiration i Grundtvigs syn på sammenhængen mellem sprog og folkelighed. Det er bemærkelsesværdigt, at den finske sprogstrid ikke har involveret højskolerne i en åndelig skyttegravskrig: her har finsktalende og svensktalende skoler kunnet eksistere sideordnet uden at være bastioner for en indædt sprogkamp. Hver folkelig fugl har frit kunne synge med sit næb. På et tidspunkt, hvor så mange af de mindre sprog er truet med at blive fortrængt af sprogimperialismen fra de store lande, bliver Grundtvigs overvejelser over modersmålet ifølge Björkstrand yderst aktuelle.

K.E. Bugge leverer en oversigt over nogle af resultaterne af et forskningsarbejde i den nu hedengangne Nornesalens og Grundtvigs Mindestuers regi. Her har man forsøgt at kortlægge udbredelsen af inspirationen fra Grundtvig uden for Norden. Indtil for fă år siden var der bestemte områder, som syntes helt utilgængelige for inspirationen fra Grundtvig: det romersk-katolske Sydeuropa, Sovjetunionen og den muslimske verden. Men siden er billedet ændret. Nu findes højskoletanken udbredt i dele af det romersk-katolske Phillipinerne, i det tidligere Sovjetunionen (bl. Skt. Petersborg) og i det muslimske Bangla-Desh, hvor der siden 1980erne er opstået $i$ alt fem grundtvigsk inspirerede højskoleinitiativer (herom mere nedenfor).

Bugge opererer med tre faser i Grundtvig-receptionen inden for den 3. verden: Eksport-modellen, som gjorde sig gældende i den første efterkrigstid, tilpasningsmodellen, som holdt sit indtog i 1960erne og endelig inspirationsmodellen, som kan forfølges fra 1980erne og frem. Det siger sig selv, at den sidste model i realiteten er den mest Grundtvigske - den peger jo i sig selv på betydningen af en interkulturel "levende vekselvirkning«. Det er en given sag, at den grundtvigske folkeoplysning er et af vore væsentligste bidrag til verdenskulturen. Men lige så sikkert er det, at den ikke står sig ved at optræde som eksportvare. Derimod kan den meget vel importeres som en nytteartikel til folkelig inspiration i et givet lokalsamfund.

Dette motiv uddybes yderligere i Holger Bernt Hansens afsluttende artikel »Education for Life or for Livelihood?«, som genoptager temaet »Grundtvig og den tredje verden « fra »Heritage and Prophecy«. Holger Bent Hansen advarer mod den alt for poserende grundtvigske selvforgabthed, der bilder sig ind at højskolen i sin specielle danske udformning er patentløsningen på ulandenes problemer. At bilde sig ind at floromvunden tale om folkehøjskolerne og myterne og sproget og andelsbevægelsen og nationalstaten, under ét: »den danske model«, er opskriften på verdens frelse, er mest af alt udtryk for en påtrængende kulturimperialisme med tydelige reminiscenser af en kolonial paternalisme, som modtagerlandene ofte - og med rette - kan føle sig pikeret over. 
Som et eksempel på en dialogisk kulturudveksling mellem den danske folkeoplysningstradition og mere lokalbestemte kulturformer fremhæver han netop skoleforsøgene i det muslimske Bangladesh det såkaldte Gonobidylaya-projekt, hvor Danida, Folkehøjskolernes Forening i Danmark er gået sammen med nogle lokale NGO-organisationer med det formål at skabe en række daghøjskoler i foreløbigt fem landsbyer. Det er ikke kostskoler og undervisningen er ikke bare i folkeoplysende forstand almendannende, den er også anlagt på udviklingen af praktiske færdigheder, som kan skabe jobs og udviklingsmuligheder for deltagerne. I en situation, hvor selve spørgsmålet om tilvejebringelse af livsmidler til at klare dagen og vejen står øverst på dagsordenen, kan det forekomme temmelig letfærdigt at fokusere på livet og livsudfoldelsen i en ophøjet og abstrakt almenhed. Det har den bengalske filosof Tagore et naturligt blik for: "Først levebrødet, dernæst livet« lyder et af hans valgsprog. I Gonobidylaya-projektet er der altså langt fra tale om en kloning af den danske højskolemodel, men om et $\mathrm{i}$ bogstaveligste forstand produktivt samarbejde til gavn og glæde for de mennesker, der frister deres tilværelse på det pågældende sted og i videre forstand for det samfund, de lever i. Altså et mønstereksempel på et egentlig »mellemfolkeligt samvirke«.

\section{Apropos:}

Medens jeg sidder og skriver på denne anmeldelse, har vi på Testrup Højskole besøg af 13 unge afrikanske radiojournalister fra Malawi, Uganda, Tanzania og Zambia, som er på efteruddannelseskursus på Danmarks Journalisthøjskole, formidlet af Danida. Det er sommer. De fleste af os er sommerligt uhøjtideligt klædt, går i shorts og sandaler og laver morgensamling og senere på dagen sanglege på græsplænen. Vore afrikanske gæster er derimod ulasteligt klædt $\mathrm{i}$ jakkesæt og adskillige af kvinderne med overtøj på. Det, der for os er en varm højsommerdag, er for dem tilsyneladende en småkold oplevelse. Også hovedet holder gæsterne koldt, selv om de bestemt er venlige, levende og opmærksomme. De er ikke for ingenting journalister af fag: ivrigt udspørgende, noterende og fotograferende. Forsøger man at anlægge en etnografisk synsvinkel på dette sociale skuespil, er der vist ikke megen tvivl om, hvem der repræsenterer civilisationen og hvem, der har »bastskørterne« på.

Og Gud ske lov for det: sådan skal det være - her er tale om et befriende ironisk memento om, at også vi danskere er en gruppe indfødte med vores stammeritualer og folkloristiske særpræg. Undertiden kan vi måske her til lands have en opfattelse af, at vi i vor danske, livsoplyste ophøjethed repræsenterer noget nær det ypperste i henseende til kulturel dannelse. Ja, nogle kunne måske ligefrem driste sig til at mene, at hvis man skulle konstruere den ideelle verdensborger, ville vedkommende ligge betragtelig nær det, vi er, som vi går og står.

Men egentlig er der jo tale om en meget forståelig og vel egentlig meget universelt gyldig (grundtvigsk) kortslutning mellem hjerte og forstand. Vi glemmer, at forstanden altid er kosmopolit, medens hjertet som regel altid er en uforbederlig hjemmefødning. Sådan er det! Anderledes kan det vel slet ikke være? Sådan skal det vel også være? Eller hvad?

Vi lader, som man siger i tv, billedet stå et øjeblik. Det kan passende optræde som et lille feltstudie i »Studies in the Creativity of Interaction«. Til personlig oplysning, opbyggelse og anfægtelse. 